DEVELOPING ENGLISH SPEAKING MATERIAL FOR THE TENTH GRADE STUDENTS OF ACCOUNTING PROGRAM AT SMK NEGERI 1 SIDIKALANG

\author{
AN ARTICLE \\ Submitted in Partial Fulfillment of the Requirements \\ for the Degree of SarjanaPendidikan
}

By:

DESLA PARAMITA TUMANGGER

Registration Number: 2133321030

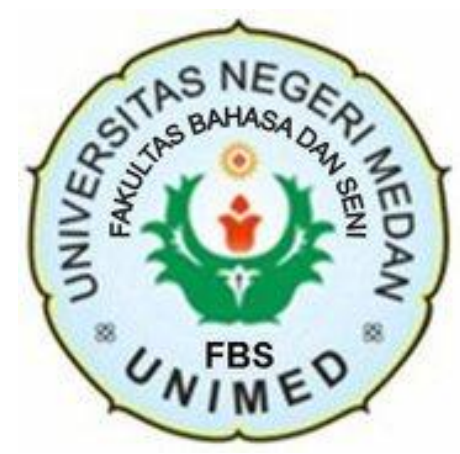

ENGLISH AND LITERATURE DEPARTMENT

FACULTY OF LANGUAGES AND ARTS

STATE UNIVERSITY OF MEDAN

2018 


\title{
ARTIKEL \\ DEVELOPING ENGLISH SPEAKING MATERIAL FOR THE TENTH GRADE STUDENTS OF ACCOUNTING PRROGRAM AT SMK NEGERI 1 SIDIKALANG
}

\author{
Disusun dan Diajukan oleh: \\ Desla Paramita Tumangger \\ NIM. 2133321030
}

Telah diverifikaasi dan dinyatakan memenuhi syarat untuk diunggah pada jurnal online

Medan, April 2018

Menyetujui

Dosen Pembimbing Skripsi I

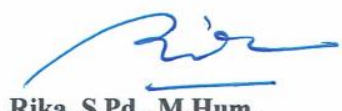

NIP. 197807172008122001
Dosen Pembimbing Skripsi II

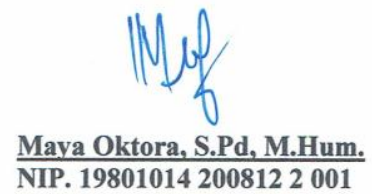

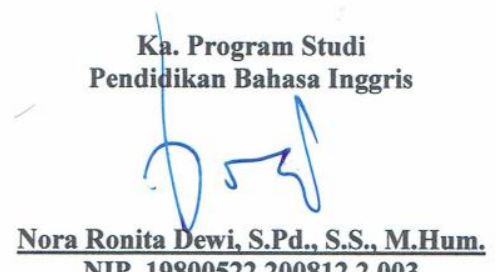

NIP. 198005222008122003 


\title{
DEVELOPING ENGLISH SPEAKING MATERIAL FOR THE TENTH GRADE STUDENTS OF ACCOUNTING PROGRAM AT SMK NEGERI 1 SIDIKALANG
}

\author{
*Desla Paramita Tumangger \\ ** Rika \\ ***Maya Oktora
}

\begin{abstract}
This research was aimed to develop English speaking materials for the students of Accounting program at SMK Negeri 1 Sidikalang especially the tenth grade. The research was conducted by Research and Development ( $R$ \& D) design through four phases; Evaluation and Need Analysis, Material Development, Material Validation and Revision and Final Product. It was conducted at SMK Negeri 1 Sidikalang. The date were gathered by administering interview to English teacher and distributing questionnaire to 10 students to get the student's needs. The result of questionnaire showed that the relevance of existing Speaking material with Accounting major just $35 \%$ (less relevant) and $90 \%$ of the students need the relevance English speaking material with their major and related to work situation. The interview and questionnaire results prove that the students need English Speaking materials which contain the appropriate knowledge or topic with the syllabus, student's level and major. The material developed into 3 units based on the basic competence on syllabus; Congratulating and Complimenting, Expressing Intention, and Giving Announcement. The product of English speaking material validated by two experts, lecturer and English teacher. The result of experts' judgment is 89.5 and it belongs to good category. The experts' validation shows that the materials are appropriate and recommended to be used for students of Accounting program especially in SMK Negeri 1 Sidikalang.
\end{abstract}

Keywords: Research and Development(R \& D), English Speaking materials, Accounting Program

\footnotetext{
*Graduate Status

***ecturer Status
} 


\section{INTRODUCTION}

\section{Background of the Study}

Efforts to improve vocational education in Indonesia have intensified since 2005, with both the MNEC (Ministry of Education and Culture) and MORTHE (Ministry of Research, Technology and Higher Education) focused on increasing the number of SMKs and tertiary vocational institutions while ensuring the quality of curriculum and achieved learning outcomes match with industry demands. Since then, the Indonesian Government has emphasized vocational education as one of the key strategies to boost the country's economic development

One of the Indonesia Governments' effort in order to empower competition with another countries as AEC' members was human resource enhancement. To support the vocational students' ability to communicate their skill, they need to comprehend English language as the international language. The international currencies of technology and commerce was create the point of view that people learn English not only for pleasure or prestige of knowing the language (Hutchinson\& Waters, 1987).

Accounting is one of the major in Vocational High School aimed to prepare the students to work as accountant that familiar with english accounting terms. The growth of industry and company forced the students have international capability including english speaking ability in order to meets jobs standard. Speaking becomes the important thing for accounting students in order they can communicate transactionally and interpersonally. The transactional function has its main purpose in conveying information and facilitating the exchange of goods and services, whereas the interpersonal function is all about maintaining and sustaining good relation between people (Harmer, 2007 :343).

But unfortunately the education system in Indonesia is still concentrated in the two main skills namely reading and writing (Andi et al). This is because most teachers only put students' ability to understand the structure of language. 
Furthermore, since speaking will not be the main subject that the students have to deal with examination, the number of the speaking materials which the students will receive in the school could be considered less than any other subject.

Learning materials must be prepared in accordance with the needs of learners, because the teaching material which is constantly addresses to their need can motivate them to achieve the learning objectives (Blagojevich, 2013). English book is the main learning sources using in Indonesia. English textbook adopted contextual teaching and learning (CTL) that has been associated with other educational theories such as experiential learning, transformative learning, and situated learning.

Particularly in Indonesia vocational school received scant attention in vocationally tailored English textbooks because publishers and governments assume that student share the same needs with general students. Most of the teacher s recognized the lack, but they do not have a vested interest in designing or developing vocational English materials because of time constraints, lack of institutional support, no professional training in language material development, and no national curriculum endorsement (Widodo, 2015). Then it is impact the English quality of vocational students in Indonesia.

Harsono (2007) stated that the English teacher have to teach their students using the prescribed textbook as the government regulation. But the existing learning materials in the prescribed textbook often lack of relationship with students major. Based on the preliminary observation the researcher found that the existing material on the textbook used by the English teacher of SMK Negeri 1 Sidikalang especially Accounting major program has no relationship with their major. 


\section{REVIEW OF LITERATURE}

It is generally known that speaking is a productive skill of language. As define that speaking is an interactive process of constructing meaning that involves producing, receiving, and processing information (Brown, 1994; Burns \& Joyce, 1997).

Its form and meaning are dependent on the context in which it occurs, including the participants themselves, their collective experiences, the physical environment, ant the purposes for speaking. It can be spontaneous, open-ended, and evolving.

Tomlinson (2011: 66 ) describes that materials is anything which is used to facilitate the learning of a language. They can be linguistic, visual, auditory or kinesthetic, and they can be presented in print, through live performance or display, or on cassette, CD-ROM, DVD or the internet.Need Analysis.Good material is the important case in teaching and learning process. Its help teacher in deliver the lesson and help the student to understand it.

Commonly in Indonesia, the learning process in school using textbook and workbook as the basic learning materials. In fact, the development of the technological progress very rapidly should be able to support the system of learning in the classroom.

Learning material based on textbook tend too bored and did not generate interest student learning. While demands of learning is creating an interactive learning for the sake of achieving the success of the delivery of the learning material.

Developing English Spaking materials refers toanything which is done by writer, teacher or larningto provide source of languange input and to exploite those source in ways designed to promote language learning (Tomlinson, 1988). It means that developing English speaking material related to some way to ellaborate or exploite some sources to produce a good material to achieve students speaking ability. 
As Tomlinson (2011) stated that materials development:

"refers to anything which is done by the writers, teachers or learners to provide sources of language input, to exploit those sources in ways which maximize the likelihood of intake and to stimulate purposeful output: I other words the supplying of information about and / or experience of the language in ways designed to promote language learning." (Tomlinson, 2011:2).

It means that development of learning is anything that teachers and learners done as the way to stimulate and facilitate learning process to achieve the learning purposes.

Evaluation is needed to know if the materials design already fulfill the learner's needs or suitable for the learners. According to Hutchinson and Waters evaluation is basically a matching process, matching needs to available solution.

Some people described ESP as simply as teaching English for any purpose that could be specific. Others, however, were more precise describing it as the teaching of English for vocational or professional purpose (Anthony, 1997, p 10). To analyze the student's need is divided into two major terms, there are :

1. Target needs, what learners need to do in the target situation, what are the linguistic elements needed to achieve specific communicative purpose. Hutinchon and Waters propose sibdivion of target needs wich is Neccesities ( Academic or occupational requirements of the target situation), Lacks ( what the learners are deficient in), and wants ( are the learners' personal expectations and hopes towards acquiring English).

2. Learning Needs, what leanrerns need to do in order to learn. Learning needs look for data in relation to the lerning situation which take into consideration learner's type, cultural awareness and profiency level in English, the available materials, the existing resources and all the information that help teacher to provide the learners with appropriate knowledge. 


\section{RESEARCH METHODOLOGY}

The research was conducted based on educational research and development $(R \& D)$. Educational research and development (R\&D) is an industry-based development model in which the findings of research are used to design new products and procedures, which then are systematically field-tested, evaluated, and refined until they meet specified criteria of effectiveness, quality, or similar standards ( Borg and Gall 2003: 569). This developmental research consist of 4 stages, as mentioned below:

1. Evaluation and Need Analysis

2. Material Development

3. Material Validation

4. Revision and Final Product

The subject of research was the students of Accounting program in Grade X consist of 10 students at SMK Negeri 1 Sidikalang. The data of the research were collected through the analysis of questionnaire and interview and documents, such as syllabus and textbook. The questionnaire was administrated to get the data of the existing english speaking learning material and th students needs and the interview was administrated to teacher to find the accurate data from the teachers about the students' needs especially in speaking comprehension. The data used in this study were: Questionnaire,Interview and Documents ( Existing Material and Syllabus).

\section{Techniques of Analysis Data}

The data of this study was the need for students of accounting program at SMK Negeri 1 Sidikalang. The data analyzed by getting the solution of the students 'problem and the appropriate English reading materials particularly procedure text. The data was analyzed as follows:Analyzing students' needs by using questionnaire and interview. The questionnaire was administrated to the students and interview was administrated to the teachers. The data was needed to evaluate the existing speaking materials and analyze the students needs. The 
document such as syllabus and textbookanalyzed to get further information. Then the researcher developed the relevant speaking materials based on needs analysis.

\section{DATA ANALYSIS AND RESEARCH FINDINGS}

Data Analysis:

\section{EVALUATION AND NEED ANALYSIS}

\section{A. Evaluation}

Table 4.1: Basic Competence for Speaking in Existing Syllabus

\begin{tabular}{|l|l|}
\hline 4.1 & $\begin{array}{l}\text { Basic Competences (Speaking) } \\
\text { menyusun teks lisan dan tulis sederhana, untuk } \\
\text { memperhatikan fungsi sosial, struktur teks, dan unsur kebahasaan, secara } \\
\text { benar dan sesuai dengan konteks. }\end{array}$ \\
\hline $\mathbf{4 . 2}$ & $\begin{array}{l}\text { Menyusun teks lisan dan tulis untuk mengucapkan dan merespon pujian } \\
\text { bersayap, dengan memperhatikan fungsi sosial, struktur teks, dan unsur } \\
\text { kebahasaan yang benar dan sesuai konteks. }\end{array}$ \\
\hline 4.3 & $\begin{array}{l}\text { Menyusun teks lisan dan tulis untuk menyatakan dan menanyakan } \\
\text { tentang niat melakukan sesuatu, dengan memperhatikan fungsi sosial, } \\
\text { struktur teks, dan unsur kebahasaan, yang benar dan sesuai konteks }\end{array}$ \\
\hline 4.4.2 & $\begin{array}{l}\text { Menyusun teks deskriptif lisan dan tulis, pendek dan sederhana, terkait } \\
\text { tempat wisata dan bangunan bersejarah terkenal, dengan memperhatikan } \\
\text { fungsi sosial, struktur teks, dan unsur kebahasaan, secara benar dan } \\
\text { sesuai konteks }\end{array}$ \\
\hline 4.5.2 & $\begin{array}{l}\text { Menyusun teks khusus dalam bentuk pemberitahuan (announcement), } \\
\text { lisan dan tulis, pendek dan sederhana, dengan memperhatikan fungsi } \\
\text { social, struktur teks, dan unsur kebahasaan, secara benar dan sesuai } \\
\text { konteks }\end{array}$ \\
\hline
\end{tabular}

Table 4.2: The Topic of Existing English Speaking Material in Textbook

\begin{tabular}{|c|c|}
\hline TOPIC & Speaking Material \\
\hline Talking about self & $\begin{array}{l}\text { Guessing Game - Who Am I? } \\
\text { Introduction Game - Party Time }\end{array}$ \\
\hline $\begin{array}{l}\text { Congratulating } \quad \text { and } \\
\text { Complimenting }\end{array}$ & $\begin{array}{l}\text { Let's play rock, paper, and scissors (makes } \\
\text { expression of congratulating for new bag, best } \\
\text { student, getting married) }\end{array}$ \\
\hline
\end{tabular}




\begin{tabular}{|l|l|}
\hline Expressing Intention & $\begin{array}{l}\text { Make up short dialogues based on the } \\
\text { situation (Biology project, Go to the movie, } \\
\text { school's anniversary) }\end{array}$ \\
\hline $\begin{array}{l}\text { Describing } \\
\text { destination and historical } \\
\text { place }\end{array}$ & $\begin{array}{l}\text { Describing interesting place (waterfall, } \\
\text { museum, temples, etc) in role play }\end{array}$ \\
\hline $\begin{array}{l}\text { Describing or presenting } \\
\text { information about a particular } \\
\text { place }\end{array}$ & Telling about interesting place \\
\hline Giving announcement & $\begin{array}{l}\text { Make announcement as the captain of class } \\
\text { for trip to Borobudur Temple }\end{array}$ \\
\hline
\end{tabular}

These speaking materials were not suitable to the students of Accounting program because these materials did not meet the needs or purposes of the students to study in relation to their major.

Table 4.3: Analysis of Teaching and Learning Evaluation

\begin{tabular}{|c|c|c|c|c|}
\hline No & Description & Score & Percentage & $\begin{array}{c}\text { Level of } \\
\text { Relevan } \\
\text { ce }\end{array}$ \\
\hline $\mathbf{A}$ & AIMS & & & \\
\hline 1 & $\begin{array}{l}\text { Existing Speaking material relevance } \\
\text { with Accounting major }\end{array}$ & 1.4 & $35 \%$ & $\begin{array}{c}\text { Less } \\
\text { relevant }\end{array}$ \\
\hline 2 & $\begin{array}{l}\text { Existing Speaking material relevance } \\
\text { with students needs }\end{array}$ & 2.0 & $50 \%$ & $\begin{array}{c}\text { Fairly } \\
\text { Relevant }\end{array}$ \\
\hline 3 & $\begin{array}{l}\text { Existing Speaking material provide } \\
\text { students speaking ability }\end{array}$ & 1.0 & $25 \%$ & $\begin{array}{c}\text { Less } \\
\text { relevant }\end{array}$ \\
\hline $\mathbf{B}$ & DESIGN AND LAYOUT & & & \\
\hline 4 & $\begin{array}{l}\text { The arrangement of the existing Speaking } \\
\text { material }\end{array}$ & 1.3 & $32.5 \%$ & $\begin{array}{c}\text { Less } \\
\text { relevant }\end{array}$ \\
\hline 5 & Content of the Speaking material & 1.2 & $30 \%$ & $\begin{array}{c}\text { Less } \\
\text { relevant }\end{array}$ \\
\hline 6 & The relevance of each speaking material & 0.8 & $20 \%$ & $\begin{array}{c}\text { Less } \\
\text { relevant }\end{array}$ \\
\hline 7 & $\begin{array}{l}\text { The topic of speaking material relevance } \\
\text { with the previous topic }\end{array}$ & 1.3 & $32.5 \%$ & $\begin{array}{c}\text { Less } \\
\text { relevant }\end{array}$ \\
\hline 8 & $\begin{array}{l}\text { Existing Speaking material provide } \\
\text { relevance media / illustration }\end{array}$ & 0.6 & $15 \%$ & $\begin{array}{c}\text { Less } \\
\text { relevant }\end{array}$ \\
\hline 9 & The appearance of illustration clear & 1.1 & $27.5 \%$ & $\begin{array}{c}\text { Less } \\
\text { relevant }\end{array}$ \\
\hline $\mathbf{C}$ & LINGUISTIC FEATURES & & & \\
\hline 10 & Grammar relevance with students ability & 1.0 & $25 \%$ & Less \\
\hline
\end{tabular}




\begin{tabular}{|c|c|c|c|c|}
\hline & & & & relevant \\
\hline 11 & $\begin{array}{l}\text { Vocabulary relevance with students } \\
\text { ability }\end{array}$ & 1.0 & $25 \%$ & $\begin{array}{l}\text { Less } \\
\text { relevant }\end{array}$ \\
\hline 12 & Provide pronunciation activity & 1.0 & $25 \%$ & $\begin{array}{c}\text { Less } \\
\text { relevant }\end{array}$ \\
\hline 13 & $\begin{array}{l}\text { Provide relevance language based on } \\
\text { topic }\end{array}$ & 0.8 & $25 \%$ & $\begin{array}{l}\text { Less } \\
\text { relevant }\end{array}$ \\
\hline $\mathrm{D}$ & TOPIC & & & \\
\hline 14 & The topic interesting & 1.1 & $20 \%$ & $\begin{array}{l}\text { Less } \\
\text { relevant }\end{array}$ \\
\hline 15 & $\begin{array}{l}\text { The existing topic appropriate with } \\
\text { students level }\end{array}$ & 1.0 & $27.5 \%$ & $\begin{array}{l}\text { Less } \\
\text { relevant }\end{array}$ \\
\hline 16 & $\begin{array}{l}\text { The existing learning material stimulate } \\
\text { students knowledge }\end{array}$ & 1.3 & $32.5 \%$ & $\begin{array}{l}\text { Less } \\
\text { relevant }\end{array}$ \\
\hline 17 & $\begin{array}{l}\text { Existing learning material appropriate } \\
\text { with students major }\end{array}$ & 1.1 & $27.5 \%$ & $\begin{array}{l}\text { Less } \\
\text { relevant }\end{array}$ \\
\hline $\mathbf{D}$ & METHOD & & & \\
\hline 18 & $\begin{array}{l}\text { Speaking activity method appropriate } \\
\text { with the topic }\end{array}$ & 1.1 & $27.5 \%$ & $\begin{array}{l}\text { Less } \\
\text { relevant }\end{array}$ \\
\hline 19 & Appropriate with students level & 1.3 & $32.5 \%$ & $\begin{array}{l}\text { Less } \\
\text { relevant }\end{array}$ \\
\hline 20 & $\begin{array}{l}\text { Existing learning method motivated } \\
\text { students }\end{array}$ & 1.2 & $30 \%$ & $\begin{array}{l}\text { Less } \\
\text { relevant }\end{array}$ \\
\hline 21 & $\begin{array}{l}\text { Existing speaking method give more } \\
\text { opportunities for speaking }\end{array}$ & 1.2 & $30 \%$ & $\begin{array}{l}\text { Less } \\
\text { relevant }\end{array}$ \\
\hline 22 & Group learning in speaking & 1.2 & $30 \%$ & $\begin{array}{l}\text { Less } \\
\text { relevant }\end{array}$ \\
\hline 23 & Applying the activity basis learning & 1.0 & $25 \%$ & $\begin{array}{l}\text { Less } \\
\text { relevant }\end{array}$ \\
\hline $\mathbf{E}$ & SKILL & & & \\
\hline 24 & $\begin{array}{l}\text { Existing speaking material elaborate with } \\
\text { another skill }\end{array}$ & 1.3 & $32.5 \%$ & $\begin{array}{l}\text { Less } \\
\text { relevant }\end{array}$ \\
\hline 25 & $\begin{array}{l}\text { Existing speaking material improve } \\
\text { students speaking ability }\end{array}$ & 1.1 & $27.5 \%$ & $\begin{array}{l}\text { Less } \\
\text { relevant }\end{array}$ \\
\hline
\end{tabular}

\section{B. Need Analysis}

Table 4. 4: Analysis of Students' Needs

\begin{tabular}{|c|l|c|c|c|}
\hline No & \multicolumn{1}{|c|}{ Description } & Score & $\begin{array}{c}\text { Percentage } \\
\text { of Students } \\
\text { Answer }\end{array}$ & $\begin{array}{c}\text { Level of } \\
\text { Needs }\end{array}$ \\
\hline A & SPEAKING MATERIAL & $90 \%$ & $\begin{array}{c}\text { Very } \\
\text { Needed }\end{array}$ \\
\hline 1 & $\begin{array}{l}\text { Do the students need the } \\
\text { speaking material }\end{array}$ & 3.6 & & \\
\hline
\end{tabular}




\begin{tabular}{|c|c|c|c|c|}
\hline & developed by teacher? & & & \\
\hline 2 & $\begin{array}{l}\text { Do the students need the } \\
\text { speaking material } \\
\text { developed by students? }\end{array}$ & 2.7 & $67.5 \%$ & Needed \\
\hline 3 & $\begin{array}{l}\text { Do the students need the } \\
\text { related speaking material } \\
\text { with Accounting major? }\end{array}$ & 3.8 & $95 \%$ & $\begin{array}{c}\text { Very } \\
\text { Needed }\end{array}$ \\
\hline 4 & $\begin{array}{l}\text { Do the students need the } \\
\text { related speaking material } \\
\text { with work situation? }\end{array}$ & 3.6 & $90 \%$ & $\begin{array}{c}\text { Very } \\
\text { Needed }\end{array}$ \\
\hline $\mathrm{B}$ & LEARNING METHOD & & & \\
\hline 5 & $\begin{array}{l}\text { Do the students need } \\
\text { students centered } \\
\text { learning? }\end{array}$ & 2.6 & $65 \%$ & Needed \\
\hline 6 & $\begin{array}{l}\text { Do the students need } \\
\text { individual speaking } \\
\text { activity? }\end{array}$ & 2.7 & $67.5 \%$ & Needed \\
\hline 7 & $\begin{array}{l}\text { Do the students need } \\
\text { activity centered } \\
\text { speaking learning? }\end{array}$ & 3.5 & $87.5 \%$ & $\begin{array}{c}\text { Very } \\
\text { Needed }\end{array}$ \\
\hline 8 & $\begin{array}{l}\text { Do the students need } \\
\text { speaking activity in } \\
\text { pairs? }\end{array}$ & 3.5 & $87.5 \%$ & $\begin{array}{l}\text { Very } \\
\text { Needed }\end{array}$ \\
\hline 9 & $\begin{array}{l}\text { Do the students need } \\
\text { small group speaking } \\
\text { activity? }\end{array}$ & 2.6 & $65 \%$ & Needed \\
\hline 10 & $\begin{array}{l}\text { Do the students need big } \\
\text { group speaking activity? }\end{array}$ & 1.5 & $37.5 \%$ & Less Needed \\
\hline 11 & $\begin{array}{l}\text { Do the students need } \\
\text { teacher centered } \\
\text { learning? }\end{array}$ & 2.8 & $37.5 \%$ & Less Needed \\
\hline 12 & $\begin{array}{l}\text { Do the students need } \\
\text { speaking activity In } \\
\text { class? }\end{array}$ & 2.6 & $65 \%$ & Needed \\
\hline 13 & $\begin{array}{l}\text { Do the students need } \\
\text { speaking activity out of } \\
\text { class? }\end{array}$ & 2.6 & $65 \%$ & Needed \\
\hline 14 & $\begin{array}{l}\text { Do the students need } \\
\text { speaking activity using } \\
\text { media? }\end{array}$ & 2.6 & $65 \%$ & Needed \\
\hline 15 & $\begin{array}{l}\text { Do the students need } \\
\text { pronunciation? }\end{array}$ & 2.6 & $65 \%$ & Needed \\
\hline 16 & $\begin{array}{l}\text { Do the students need } \\
\text { longer time allocation for } \\
\text { speaking? }\end{array}$ & 2.5 & $62.5 \%$ & $\begin{array}{c}\text { Fairly } \\
\text { Needed }\end{array}$ \\
\hline
\end{tabular}




\begin{tabular}{|c|c|c|c|c|}
\hline $\mathrm{C}$ & \multicolumn{4}{|c|}{ LINGUISTIC FEATURES } \\
\hline 17 & $\begin{array}{l}\text { Do the students need } \\
\text { grammar ability? }\end{array}$ & 2.9 & $72.5 \%$ & Needed \\
\hline 18 & $\begin{array}{l}\text { Do the students need } \\
\text { vocabulary activity? }\end{array}$ & 2.7 & $67.5 \%$ & Needed \\
\hline 19 & $\begin{array}{l}\text { Do the students need } \\
\text { pronunciation ability? }\end{array}$ & 2.7 & $67.5 \%$ & Needed \\
\hline 20 & $\begin{array}{l}\text { Do the students need } \\
\text { language function } \\
\text { ability? }\end{array}$ & 2.7 & $67.5 \%$ & Needed \\
\hline 21 & $\begin{array}{l}\text { Do the students need } \\
\text { sentences arrangement } \\
\text { ability? }\end{array}$ & 2.8 & $70 \%$ & Needed \\
\hline $\mathrm{D}$ & \multicolumn{4}{|l|}{ ASSESMENT } \\
\hline 22 & $\begin{array}{l}\text { Do the students need oral } \\
\text { assessment? }\end{array}$ & 2.8 & $70 \%$ & Needed \\
\hline 23 & $\begin{array}{l}\text { Do the students need task } \\
\text { assessment? }\end{array}$ & 3.6 & $90 \%$ & $\begin{array}{l}\text { Very } \\
\text { Needed }\end{array}$ \\
\hline
\end{tabular}

a. Interview

The result of the interview showed that the teacher realized that the existing speaking material can't fulfill the students need as Accounting major. The teacher also describes the speaking activity in class that just follow the textbook which lack of creative activity and the topic is too general.

\section{MATERIAL DEVELOPMENT}

Table 4.5: Topic for Developed Speaking Material

\begin{tabular}{|c|c|}
\hline Core & Core Com \\
\hline $\begin{array}{l}\text { 1. Congratulating and Complimenting } \\
\text { (Write oral and written text to } \\
\text { congratulating and complimenting and } \\
\text { responds usually use in office related to } \\
\text { employee' work result) } \\
\text { 2. Intention } \\
\text { (Write oral and written text to Express } \\
\text { intention, especially in office). }\end{array}$ & $\begin{array}{l}\text { 1. Understanding, purpose, and } \\
\text { role of Accounting } \\
\text { 2. Special profesion in } \\
\text { Accounting } \\
\text { (Public accountant, tax } \\
\text { accounting, government } \\
\text { accountant) } \\
\text { 3. Business transaction of } \\
\text { services company, trade } \\
\text { company and manufacture }\end{array}$ \\
\hline
\end{tabular}




\section{Giving Announcement}

(Write oral and written text to giving announcement, especially use in office)
4. Applying ledger

5. Financial report

\section{English Speaking Material Writing}

The speaking material writing followed the rule of Scientific Approach. There are some steps learning method based on scientif approach, but it can just used some steps based on necessities; Observing, Asking, Associating, Communicating.

\section{MATERIAL VALIDATION}

Table 4.6: The Score of Expert Judgment on English Speaking Materials

\begin{tabular}{|l|l|l|l|l|}
\hline No & Aspect & Expert 1 & Expert 2 & Category \\
\hline 1 & Content & 34 & 35 & Good \\
\hline 2 & Process & 21 & 24 & Good \\
\hline 3 & Language Features & 12 & 14 & Good \\
\hline 4 & Layout & 20 & 20 & Very Good \\
\hline & Total & 87 & 92 & Good \\
\hline
\end{tabular}

$$
\begin{aligned}
& K=\frac{F}{n \times I \times r} \times 100 \\
& =\frac{87+92}{5 \times 20 \times 2} \times 100 \\
& =\frac{179}{200} \times 100 \\
& =89.5(\mathrm{Good})
\end{aligned}
$$




\section{REVISION AND FINAL PRODUCT}

Table 4.7: The Revision of Content, Process,Linguistic Features and Layout.

\begin{tabular}{|l|l|l|l|}
\hline No & Components & Expert 1/ revision & Expert 2 / revision \\
\hline 1 & Content & $\begin{array}{l}\text {-Some exercises are not for } \\
\text { Speaking. } \\
\text {-The step based on scientific } \\
\text { approach are incorrect } \\
\text {-Use the grammar and } \\
\text { language that suitable with } \\
\text { students grade }\end{array}$ & $\begin{array}{l}\text {-The content too } \\
\text { difficult } \\
\text {-Give more activity for } \\
\text { students speaking in } \\
\text { group }\end{array}$ \\
\hline 2 & Process & Attractive activity & More task \\
\hline 3 & $\begin{array}{l}\text { Linguistic } \\
\text { Features }\end{array}$ & Grammar and vocabulary & $\begin{array}{l}\text { There was inappropriate } \\
\text { vocabulary. Grammar } \\
\text { error }\end{array}$ \\
\hline 4 & Layout & No Revision & No Revision \\
\hline & & & \\
\hline
\end{tabular}
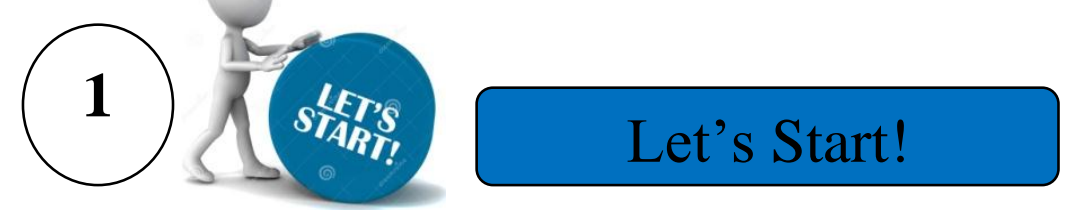

TASK 1. Look at the pictures below. What do you think about the pictures? What would you say if someone you know gets success? Discuss in pairs and explain by your own words briefly!
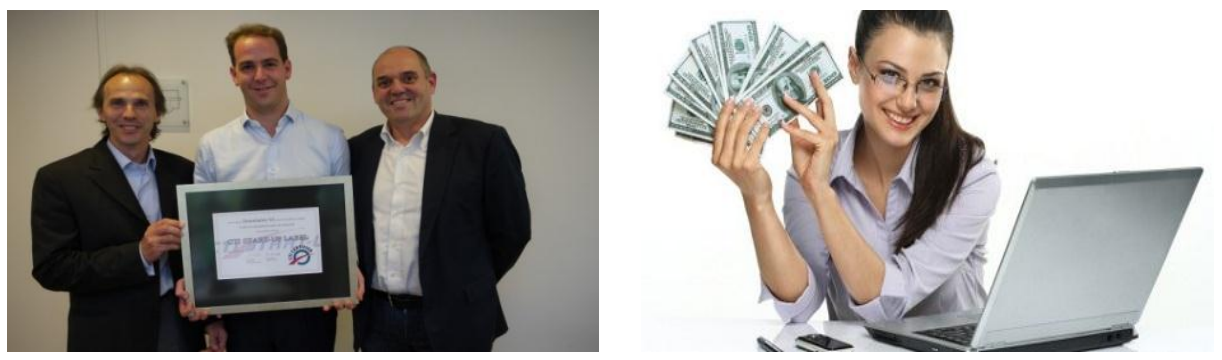

CONCLUSIONS AND SUGGESTIONS

\section{Conclusions}

Generally, the existing speaking materials were less relevant with the needs of students of accounting program. The topics were not relevant with the accounting 
which made the students were less motivated in learning English. In terms of tasks, they were not well - designed because the tasks did not help the students to promote and enrich their speaking skill.

The speaking materials needed by the students in the new course book were the relevant and useful material with work situation, accounting service. The topics needed in work situation such as understand the aims of Accounting, fields who needs aaccounting, kinds of ccompany, transaction and financial report.

The design of speaking material was scientific approach based on curriculum 2013. The structure of the material in each units followed the steps observing, questioning, exploring, associating, communicating and reflection as additional activity. The contents encouraged students to practice more and fostering the students speaking ability.

\section{Suggestions}

1. The teacher should be able in considering the students' needs, so they can develop the materials that relevant to the students' major, in this case the Accounting major.

2. Students should help the teachers in finding the students' needs and speak their mind on what they lack, need and want

3. School faculties or the institution also have to take an active role in choosing the learning materials used in the teaching - learning process.

4. It's suggested for the English teacher to use this material to increase the students' speaking ability easier and related to their major and for the other researcher who develop the English speaking material for accounting program. 


\section{REFERENCES}

Anonymous. AEAN Economic Community [Online]. Retrieved from : Association of Southeast Asian Nations. http://asean.org/asean-economic-community/ on June 12, 2017.

Ampa, T. A. (2013). The Students Needs in Developing Learning Materials for Speaking Skills in Indonesia. Journal of Education and practice Vol. 4, No. 17.

Basturkmen, H. (2010). Developing Course in English for Specific Purposes. New Zealand : University of Auckland.

Bojović, M. (2006). Teaching Foreign Language for Specific Purposes: Teacher Development. Association of Teacher Education in Europe, 31st Annual ATEE Conference. Retrived May 17, 2017.

Borg, W. R \& Gall, M.D. (1983). Educational Research: An Introduction Fourth Edition. New York : Longman.

Brown, D. H ( 2001). Teaching by Principles : An Interactive Approach to Language

Pedagogy. New York : Longman

BSNP (Badan Standar Nasional Pendidikan). (2015). National Standard in Education for Senior High School and Vocational High School.

Bygate, M. (1987). Speaking. Oxford : Oxford University Press.

Derakshan, A., Khalili, N.A., Beheshti, F. (2016) Developing EFL Learner's Speaking Ability, Accuracy and Fluency. Canadian center of Science and Education: English Languange and Literature Studies, Vol 6 (2) 177-186

Efrizal Efrizal, D. (2015). The Use of Communicative Language Teaching in

Developing Supplementary Teaching Speaking Materials for Second Year Students of Senior High School at Darussalam Islamic Boarding School of Kepahiang, Bengkulu, Indonesia. Bengkulu : IAIN Bengkulu

Febriatun. L (2016). Developing English Speaking Materials for Xth grade of

Hotel Accomodation Department in SMK PI Ambarukmo 1 Sleman. Yogyakarta : Yogyakarta State University

Harmer, J. (2001). The Practise of English Language Teaching Third Edition.

Cambridge : Longman

Harsono, M, Y. ( 2007). Developing Learning Materials for Specific Purposes.

TEFLIN Journal. 18(2) 
Hutinchon, T., and Waters, A. (1987). English for Specific Purposes : A Learning-centred Approach. Cambridge : Cambridge University Press

Jianing, X. (2007). Storytelling in the EFL Speaking. Journal of TESL Vol. 12, No. 11, Retrivred on May 16, 2017.

Lumbannahor, B. (2016). Developing English Speaking Material for Students of Business and Management Program at Vocational School. Medan :Universitas Negeri Medan

Menteri Pendidikan Nasional. (2013). Keputusan Direktur Jenderal Pendidikan

Menengah Kementerian Pendidikan dan Kebudayaan Nomor : 7013/D/KP/ 2013 tentang Spektrum Keahlian Pendidikan Menengah Kejuruan.

Nastiti, R. (2014). Developing English Speaking Materials for English Tutorial Program of Intermediate Level Students of International Accounting Education Study Program at the centre for Language

Nunan, D. (1989). Designing Task for Communication. Cambridge : Cambridge University Press.

Puji, H. (2015). The Development of Vocational English materials from a Semiotic Perspective : Participatory Action Research. Australia : University of Adelaide

Tomlinson, B. (1998). Material Development in Language Teaching. Cambridge : Cambridge University Press

Tomlinson, B. (2013). Developing Materials for Language Teaching. Cambridge : Cambridge University Press.

Richard, C. J. (1990). The Language teaching Matrix. Cambridge : Cambridge University Press.

Paker, SMK Negeri 1 Sidikalang Website. (2017). Visi dan Misi [Online].

Retrived from : www.smkn1sidikalang.sch.id on May 05,2016.

Widodo, P.H .( 2015). Development of Vocational English Materials from a Social Semiotic Perspective : Participatory Action Research. Australia : University of Adelaide 